\title{
BMJ Open Limited implementation of the framework convention on tobacco control's tobacco tax provision: global comparison
}

\author{
Heikki Hiilamo, ${ }^{1,2}$ Stanton Glantz ${ }^{3}$
}

To cite: Hiilamo H, Glantz S. Limited implementation of the framework convention on tobacco control's tobacco tax provision: global comparison. BMJ Open 2018:8:e021340. doi:10.1136/ bmjopen-2017-021340

- Prepublication history for this paper is available online. To view these files please visit the journal online (http://dx.doi. org/10.1136/bmjopen-2017021340).

Received 22 December 2017 Revised 23 August 2018 Accepted 23 August 2018

Check for updates

(C) Author(s) (or their employer(s)) 2018. Re-use permitted under CC BY-NC. No commercial re-use. See rights and permissions. Published by BMJ.

${ }^{1}$ VID Specialized University, 0slo, Norway

${ }^{2}$ Social and public policy, Department of Social Research, University of Helsinki, Helsinki, Finland

${ }^{3}$ Center for Tobacco Control Research and Education, Philip R. Lee Institute for Health Policy Studies, Helen Diller Family Comprehensive Cancer Center, Department of Medicine, University of California, San Francisco, San Francisco, California, USA

Correspondence to Professor Heikki Hiilamo; heikki.hiilamo@helsinki.fi

\section{ABSTRACT}

Objective To quantify changes in tobacco tax rates and cigarette affordability after countries ratified the WHO Framework Convention on Tobacco Control (FCTC) using with the WHO MPOWER standards.

Methods We used logistic regression to assess the association of FCTC ratification with adoption of at least $50 \%$ and $75 \%$ (high) of retail price tobacco tax rates for the most sold brands in countries, accounting for years since ratification and other covariates. We also compared cigarette affordability in 2014 with 1999.

Results By 2014, 44\% of high-income countries had taxes above $75 \%$ of retail value compared with $18 \%$ in 1998/1999. In 15 years, 69 countries increased the tobacco tax rate, 33 decreased it and one had the same tax rate. FCTC ratification was not associated with implementing high tobacco taxes. More fragile countries in terms of security, political, economic and social development were less likely to have at least $50 \%$ and 75\% tobacco tax rates in 2014 compared with 1999. The higher the cigarette prices in 1999 the less likely the countries were to have at least $75 \%$ tobacco tax rates in 2014. However, cigarettes were less affordable in 2014 than in 1999 in countries that had ratified FCTC earlier. Conclusions Despite widespread FCTC ratification, implementing higher tobacco taxes remains incomplete. Guidelines for FCTC Article 6 implementation should assign definite targets for tobacco taxes and for implementation of a tax escalator that gradually increases taxes to match rising income levels. Fragile countries are less likely to have high tobacco taxes and less affordable cigarettes. The tobacco control community should intensify efforts to help fragile countries improve performance in FCTC implementation both through strengthening their administrative and technical capacity and through supporting basic functions of government.

\section{INTRODUCTION}

Raising tobacco taxes is an effective strategy to reduce tobacco use. ${ }^{1-3}$ On average a $10 \%$ price increase will reduce tobacco use by $4 \%$ in high-income countries and by $5 \%$ among low-income and middle-income countries. ${ }^{4}$ Article 6 of the WHO Framework Convention on Tobacco Control ${ }^{5}$ (FCTC) commits parties
Strengths and limitations of this study

- We assessed changes in tobacco taxes and prices over 15 years in 103 countries.

- We used WHO's own standards for effective tax rates.

- The willingness and ability of states to implement effective tobacco taxes was measured through state fragility index.

- The limitation of the study is that we could not analyse how the tobacco companies respond to the tax increase.

- The baseline data came from two different data sources.

to implement 'tax policies and, where appropriate, price policies, on tobacco products so as to contribute to the health objectives aimed at reducing tobacco consumption'. ${ }^{5}$ Article 6 implementation guidelines ${ }^{6}$ recommend tax policies which take into account tobacco products' price elasticity (the rate by which tobacco consumption decreases as result of price increases) and income elasticity (the sensitivity of tobacco consumption to income changes) to make tobacco products less affordable over time, but does not set specific targets for taxes or prices.

Tobacco industry tactics to block tax increases have a major influence on tax rates, and industry responses to tax increases have a major effect on cigarette prices. Tobacco taxes are politically difficult to raise because tobacco companies fight tax increases ${ }^{2}$ by commissioning research claiming economic benefits of tobacco, creating alliances, ${ }^{7}$ including with progressive organisations, ${ }^{8}$ lobbying ministries of finance with poor knowledge of public health and FCTC requirements, ${ }^{9}$ and arguing tax increases drive illicit trade ${ }^{2}$ and hurt disadvantaged groups. ${ }^{81011}$ They also learnt how to cope with tax increases and sometimes actually benefit from them by overshifting 
taxes on premium brands to increase profits while downshifting taxes on ultra-low-price brands to cushion the effects of tax increases on total consumption. ${ }^{12-15}$ Even a series of substantial tax increases, such as in Australia, ${ }^{16}$ may not increase the tax rate if the industry keeps overshifting tax increases to prices. In this sense, tax rates can be a relatively poor indicator of cigarette prices.

WHO established the MPOWER measures in 2008 to scale up key FCTC demand reduction measures including tobacco taxes. MPOWER emphasises that 'increasing the price of tobacco through higher taxes is the single most effective way to encourage tobacco users to quit and prevent children from starting to smoke'. ${ }^{2}$ A key finding of the 2015 MPOWER report was that taxes were the least implemented MPOWER measure with only $10 \%$ of the world's population (living in 33 countries) covered by taxes of at least $75 \%$ of retail price. ${ }^{2}$ This paper assesses the association of FCTC ratification with implementing tobacco taxes by analysing changes in tax rate using the MPOWER standard and cigarette affordability. In addition, we assess the role of state capacity and previous tax and price levels ${ }^{17}$ on taxes in 2014 .

\section{METHODS \\ Data}

Data on the tobacco tax rate, including specific excise, ad valorem excise, import duties, value-added tax (VAT) and other taxes were obtained from the WHO Report on the Global Tobacco Epidemic 2015 public dataset for 2014. ${ }^{19}$ This dataset includes information collected by WHO in-country experts as of 31 December 2014 on the prices of the most-sold brand of cigarettes (both in local currency and in US\$) and cigarette taxes. Information on the taxation of cigarettes (and when possible, most commonly used tobacco products) was collected from ministries of finance. (Because WHO did not report tax data for Syria in 2014, we used the data from 2012 for 2014.) In countries where different taxes applied to cigarettes based on length, quantity produced or type (eg, filter vs non-filter), the rate that applied to the most popular brand was used to calculate the tax rate.

We obtained baseline pre-FCTC taxes using the 1999 World Bank (WB) survey of 64 countries that reported the share of cigarette taxes (including VAT) as a percentage of the retail price of a pack of cigarettes ${ }^{20}$ supplemented by the tobacco industry's International Tobacco Documentation Centre's ${ }^{21} 1998$ International Fiscal Guide to Tobacco that mapped international taxation, price and tariff policies. ${ }^{22}$

Tobacco tax rate is the portion of the price represented by all taxes, including VAT for the most-sold brand of cigarettes, is our outcome variable. We studied two outcome variables derived from MPOWER standards in the WHO Report on the Global Tobacco Epidemic 2015: Raising Taxes on Tobacco: (1) taxes that totalled at least $75 \%$ of retail price, the highest MPOWER standard, ${ }^{2}$ and (2) taxes that totalled at least $50 \%$ of retail price, the second highest standard. ${ }^{2}$ FCTC Article 6 does not set targets on tobacco prices. The expectation in FCTC and MPOWER is that if the manufacturers increase wholesale prices so that the overall tax rate drops below $75 \%$ or $50 \%$, the government would increase taxes so that the tax share would go above $75 \%$ or $50 \%$.

To analyse the income level of the countries we used WB 2016 gross national income (GNI) categories $^{23}$ : low-income countries were defined as those with a GNI per capita of $\$ 1045$ or less in 2014; middle-income economies, \$1046-\$12 735; high income, $\$ 12736$ or more. Lower-middle-income and upper-middle-income economies were separated at a GNI per capita of $\$ 4125$. Since our sample included only eight low-income countries, after cross tabulation analysis, we combined low-income and lower-middle-income categories in the regression analysis. We used information on cigarette prices expressed in nominal US\$ in 1998/1999.

We analysed the association of FCTC with affordability of cigarettes by using the fraction of per capita gross domestic product (GDP) that would be needed to buy 100 packs of the most sold cigarette brand. This method is a more comprehensive and representative measure of income across countries in different income levels than, for example, surveys of wages. ${ }^{24}$ We used price data described above and WB data for GDP per capita for 1999 and $2014 .{ }^{23}$ In addition, we used the growth of GDP per capita from 1999 to $2014^{23}$ ( (2014 GDP-1999 GDP)/1999 GDP, GDP expressed in 2014 US\$) as an independent variable on the assumption that cigarettes would be more affordable in 2014 among those countries where the rise in income level was the fastest. We assume that changes in GDP over the 16-year period reflect changes in disposable income.

\section{Other variables}

To study the willingness and ability of states to implement public policies, we used Marshall and Cole' ${ }^{25}$ State Fragility Index. This index scores all countries with population above 500000 in four performance dimensions: security, political, economic and social. Previous literature has shown that state fragility matters for implementing effective cigarette health warnings. ${ }^{17} 18$ The index gives higher scores for more fragile countries (Sudan scored 23 while the 15 most stable countries scored 0 ) but does not place countries into different categories. We averaged scores for 2007, 2010 and in 2013 to test whether more fragile countries were less likely to have high tobacco taxes in 2014. By more fragile countries, we refer to those countries which score higher on Marshall and Cole's State Fragility Index.

We studied the role of previous tax and price levels on tax rate in 2014 with two variables, tobacco tax rates in $1998 / 1999$ and price of most sold cigarette packs in US\$ in 1998/1999. We tested whether countries with higher cigarette taxes and higher price cigarettes in 1998/1999 were more likely to have high tax rates in 2014. 


\section{Statistical analysis}

Logistic regression was used in separate analyses with $75 \%$ and $50 \%$ tax rates in 2014 as the outcome variable. We studied the effect of FCTC by calculating the number of years since FCTC ratification as of 2014. We set years since ratification to 0 for countries that ratified the FCTC in 2014 (El Salvador, Ethiopia and Zimbabwe), had signed but not ratified the FCTC as of the end of 2014 (Argentina, Cuba, Haiti, Morocco, Mozambique, Switzerland and the USA), or had not signed or become parties to the FCTC by January 2016 (Andorra, Dominican Republic, Eritrea, Indonesia, Liechtenstein, Malawi, Monaco, Somalia). Countries that already had a tax rate of $50 \%$ (final sample used $n=44)$ or $75 \%(n=88)$ in $1998 / 1999$ were excluded from the analysis.

Our analysis has $80 \%$ statistical power (with $\alpha=0.05$ ) to detect an OR by a factor of 1.25 (or 0.80 ) associated with FCTC ratification.

We also used logistic regression to analyse the effect of the FCTC on cigarette affordability by assigning a value of 1 for those countries where cigarettes were less affordable in 2014 than in 1999 and 0 where cigarettes were more affordable. We tested interaction between state capacity and FCTC ratification to see if more fragile countries were slower in ratifying FCTC. We also ran a sensitivity analysis to test if cigarettes are less affordable in countries with extensive tobacco control measures.
We used $\mathrm{R}$ functions glm and minEffect.VSMc.logistic from powerMediation for the analysis.

\section{Patient and public involvement}

Patients or public were not involved in the study.

\section{RESULTS}

Tobacco tax rates have not uniformly increased from $1998 / 1999$ to 2014 as shown in figure 1 where the countries are ranked by their tax rate in 1998/1999. The average tax rate increased from $53 \%$ of the price of the most sold cigarette brands in 1998/1999\% to 58\% in 2014 . In those 15 years, 69 countries increased the tobacco tax rate, 33 decreased it (30 FCTC ratifying countries) and 1 country (Austria) had the same tax rate.

In 1998/1999 only eight (18\%) of high-income, two (8\%; Brazil and Costa Rica) upper-middle-income, one lower-middle-income country (4\%, Sri Lanka) and none of the low-income countries had a tax above $75 \%$ of the retail price (table 1). By 2014, $44 \%$ of high-income countries had taxes above $75 \%$ of retail value. The progress was slow among higher-income and lower-middle-income countries with just one additional country complying in each income category and no low-income country.

In 1998/1999, 37 (82\%) of high-income countries had taxes that comprised above $50 \%$ of retail price, while only

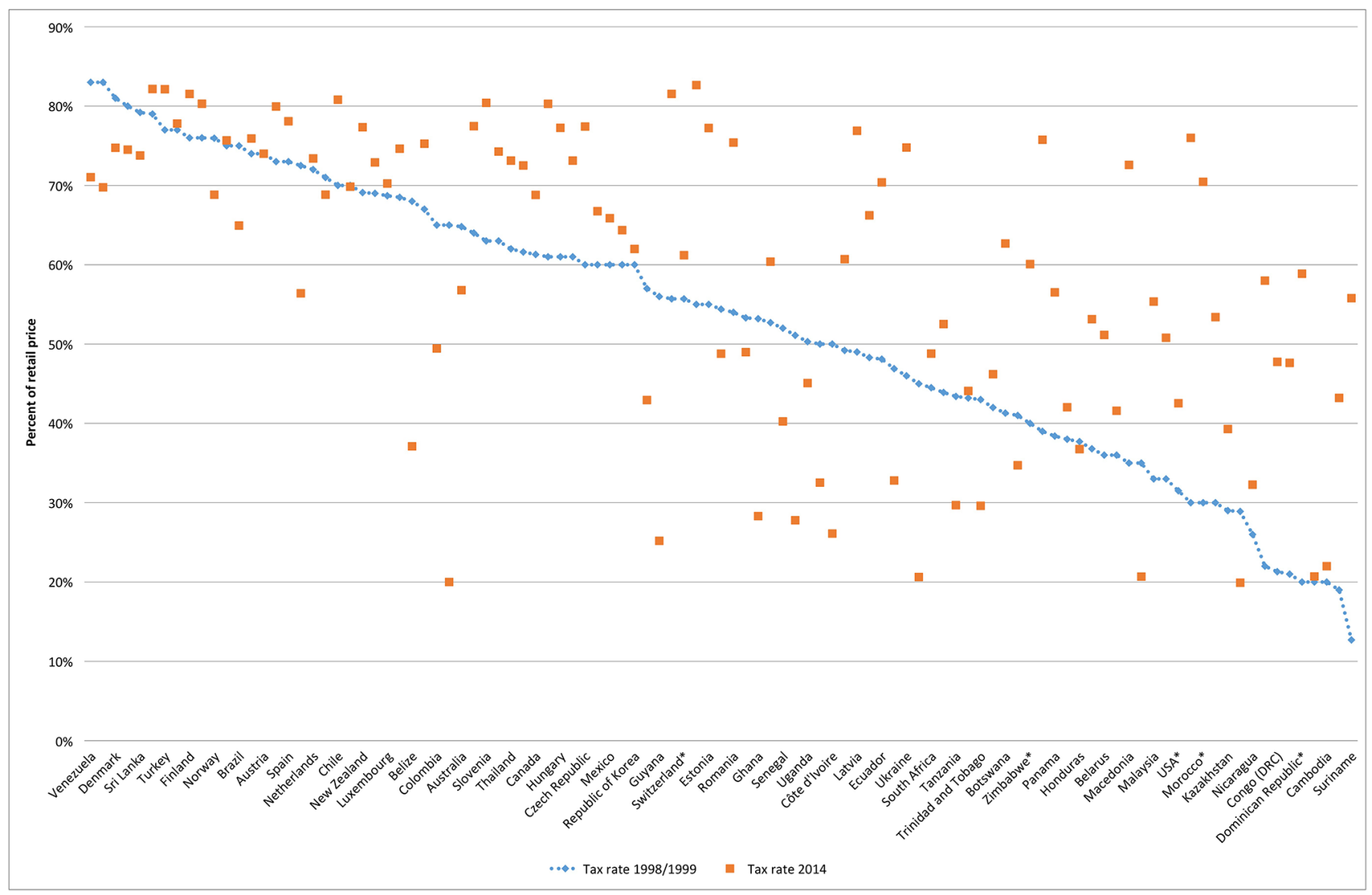

* Country has not ratified FCTC.

Figure 1 Tobacco tax rates in 1998/1999 and 2014 as per cent of retail price. FCTC, Framework Convention on Tobacco Control. 
Table 1 Countries with $75 \%$ and 50\% tobacco tax rates in 1998/1999 and 2014 by income group

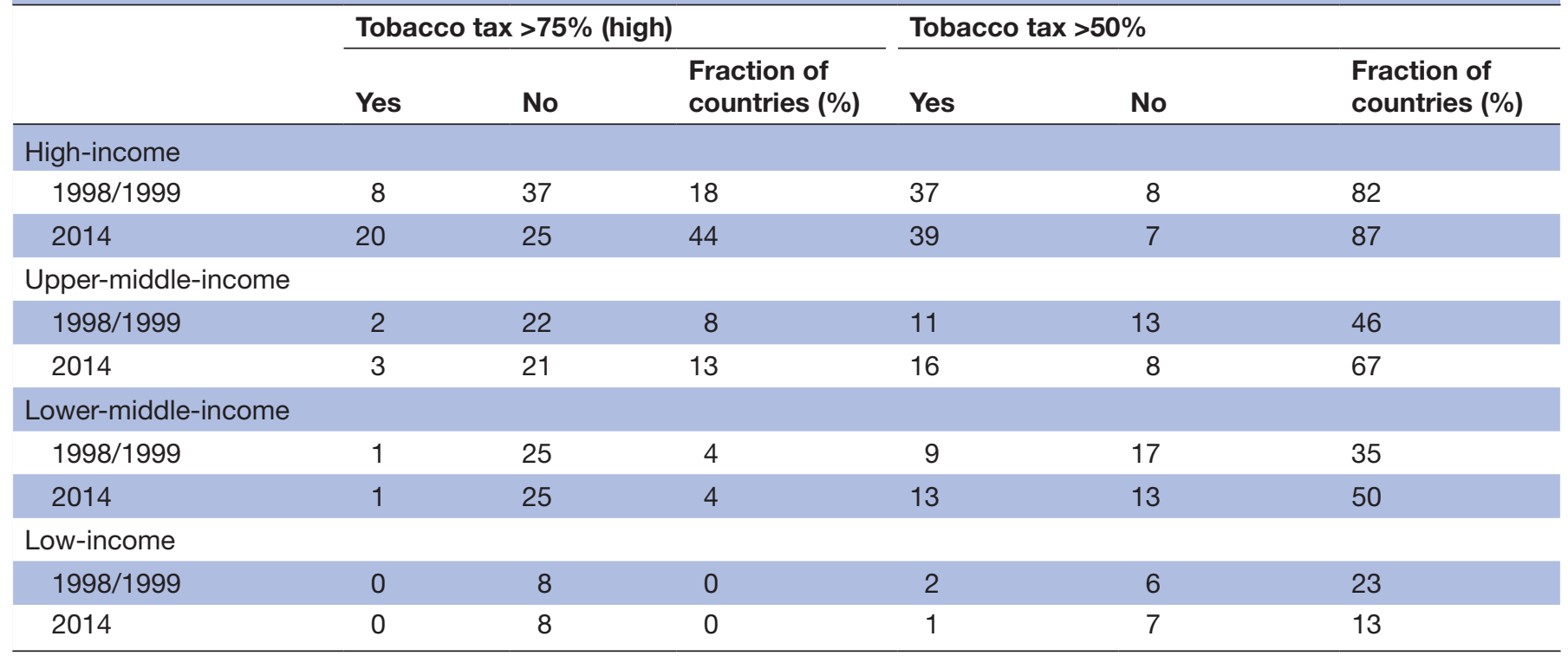

$11(46 \%)$ of higher-middle-income countries, $9(35 \%)$ of lower-middle-income countries and $2(23 \%)$ low-income country had that tax rate. By 2014, 39 (87\%) of high-income countries had taxes above $50 \%$ of retail price, as did $16(67 \%)$ of upper-middle -income countries, $13(50 \%)$ of lower-middle-income countries and 1 (13\%) low-income country (Zimbabwe).

Forty-five countries changed WB status during the observation period. The following countries changed from low-income countries to lower-middle-income countries: Bangladesh, Cambodia, Cameroon, Côte d'Ivoire, Ghana, Honduras, India, Kenya, Lesotho, Nicaragua, Nigeria, Pakistan and Vietnam. The following countries changed from lower-middle income countries to upper-middle income countries: Algeria, Belarus, Belize, Bulgaria, Columbia, Costa Rica, Dominican Republic, Ecuador, Fiji, Guyana, Jamaica, Kazakhstan, Macedonia, Namibia, Panama, Romania, Russia, Suriname and Thailand. The following countries changed from upper-middle-income countries to high income countries: Barbados, Chile, Czech Republic, Estonia, Hungary, Malta, Poland, Republic of Korea, Slovakia, Trinidad and Tobago and Uruguay. Latvia and Lithuania changed from lower-income countries to high-income countries. No country changed to a lower income group.

The logistic regression showed that time since FCTC ratification was not associated with implementing high tobacco taxes (table 2). More fragile countries were less likely to have $75 \%$ and $50 \%$ tobacco tax rates in 2014 . Countries with higher cigarette prices in 1998/1999 were more likely to have $75 \%$ tax rates in 2014 . Countries with higher tax rates in 1998/1999 were more likely than countries with lower tax rates in 1998/1999 to have $75 \%$ tobacco tax rates in 2014 . To test overall effects, we calculated a linear regression model for all countries in our sample with tax rates in 2014 as the dependent variable and FCTC ratification, tax rate in 1999, price in 1999 and state capacity as independent variables $\left(\mathrm{R}^{2}=0.48\right)$. FCTC ratification and price were not statistically significant ( $p>0.7$ and $p>0.3$, respectively). The coefficients for tax rate in 1999 were $0.40(\mathrm{p}<0.001)$ and for state capacity $-1.58(p<0.001)$. The variance inflation factors in the first model ranged from 1.08 to 1.68 and in the second model from 1.04 to 1.12 , well below the threshold for multicollinearity concern.

Table 2 Odds of passing high standard tobacco taxes by 2014 (among non-compliant countries in 1998/1999)

\begin{tabular}{|c|c|c|}
\hline & Tobacco tax $\geq 75 \%$ of retail price (high) & Tobacco tax $\geq 50 \%$ of retail price \\
\hline Years since FCTC ratification & 1.04 (0.81 to 1.43$)$ & $0.94(0.76$ to 1.15$)$ \\
\hline Price in 1998/1999 & $0.31^{*}(0.10$ to 0.73$)$ & 0.78 (0.22 to 2.78$)$ \\
\hline State capacity & $0.67 \dagger(0.49$ to 0.83$)$ & $0.86^{*}(0.74$ to 0.99$)$ \\
\hline
\end{tabular}

${ }^{*} \mathrm{P} \leq 0.05,+\mathrm{P} \leq 0.01$.

FCTC, Framework Convention on Tobacco Control. 


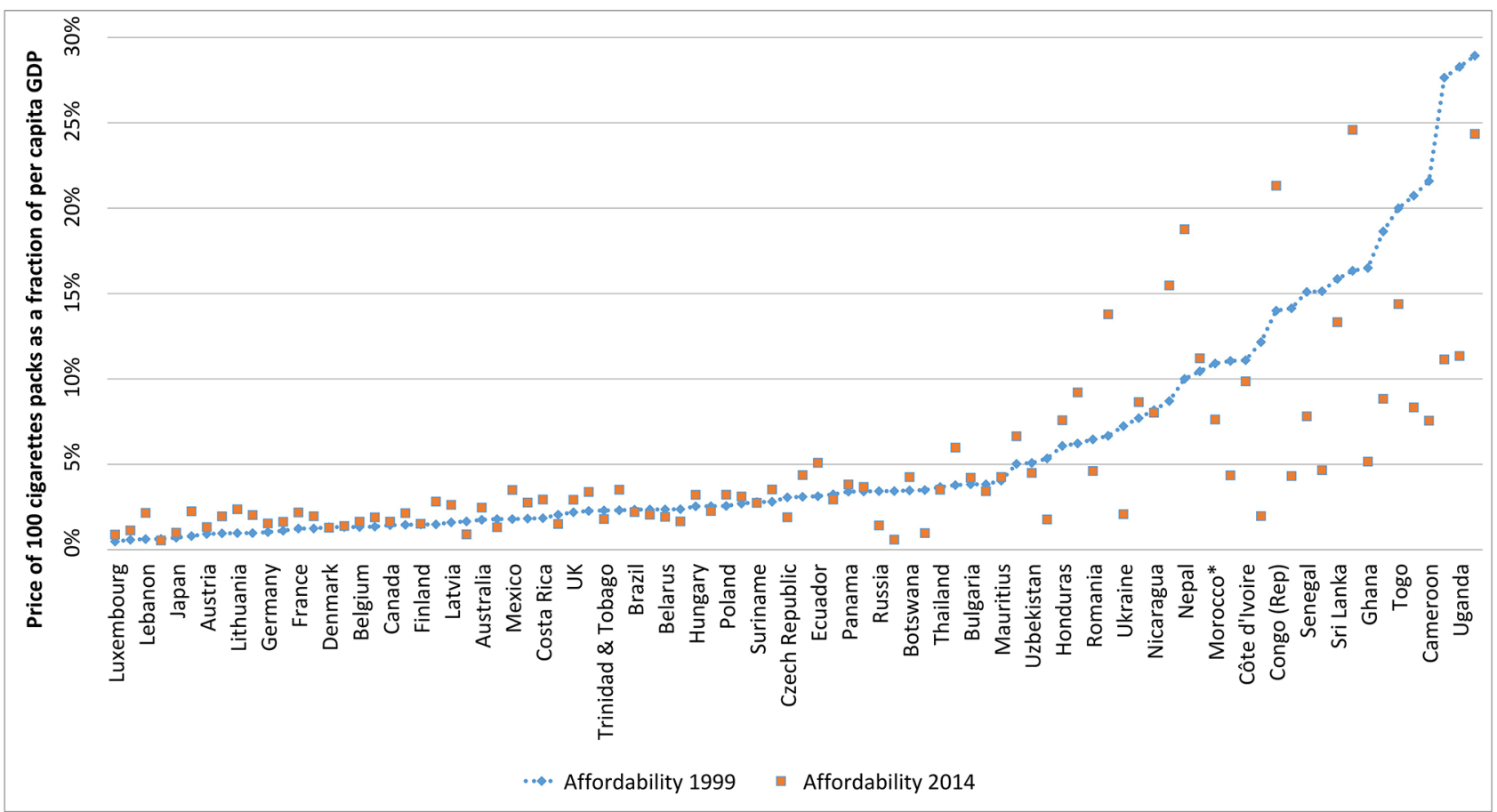

* Country has not ratified FCTC.

Figure 2 Shares of price of 100 cigarette packs of GDP per capita in 1999 and 2014 as per cent of retail price. FCTC, Framework Convention on Tobacco Control; GDP, gross domestic product.

As a sensitivity analysis, we also ran ordinary least squares (OLS) regression with actual tax rate in 2014 as the dependent variable for the whole sample. We used the same independent variables as in logit analysis. Tax rate in 1999 was positively associated with tax rate in 2014 (coefficient $0.41, \mathrm{p}=0.0003$ ) and lack of state capacity was negatively associated with tax in 2014 (coeff. -1.52, $\mathrm{p}=0.00001$ ). The results were essentially the same as the logistic regression analysis.

There were large differences in affordability of cigarettes across countries in both 1999 and 2014 (figure 2). At the lower end of the range, in 2014 less than $1 \%$ of per capita GDP was required to buy 100 packs of the most sold cigarette brands in Luxembourg, while at the upper end in Tanzania the corresponding figure was $24.6 \%$ (28.9\% in 1999). Cigarettes became less affordable between 1999 and 2014 in 51 countries and more affordable in 40 countries. Cigarettes had become less affordable in $73 \%$ of high-income countries (27/37), $61 \%$ of upper-middle-income countries (14/23) and $31 \%$ of lower-middle and low-income countries (10/32). Ratifying the FCTC earlier was associated with cigarettes becoming less affordable in 2014 implying perhaps that countries with affordable cigarette prices in 1999 were quicker to ratify the FCTC and implement its tax provision (table 3). Cigarettes became more affordable in countries with high rates of per capita GDP growth between 1999 and 2014. Lack of state capacity was associated with lower odds for having less affordable cigarettes. The variance inflation factors ranged from 1.04 to 1.10 , indicating no multicollinearity problems.
As a sensitivity analysis, we also ran OLS regression with cigarette affordability in 2014 as the dependent variable for the whole sample. We used the same independent variables as in logit analysis. The direction of association was again similar as in logit analysis. Ratifying the FCTC earlier was positively associated with cigarettes becoming less affordable in 2014 (coeff. 0.04, $\mathrm{p}=0.03$ ), while GDP growth (coeff. $-0.10, p=0.001$ ) and lack of state capacity (coeff. $-0.02, p=0.001$ ) were negatively associated with having less affordable cigarettes.

\section{DISCUSSION}

Our results confirm earlier findings showing slow progress in meeting the $75 \%$ or $50 \%$ tobacco tax rate targets among low-income and middle-income countries. ${ }^{2} 26$ Likewise, our results support concerns ${ }^{2}$ that FCTC Article 6 has not, in general, led countries to implement high

Table 3 Odds of cigarettes being less affordable by 2014

\begin{tabular}{lc}
\hline Variable & OR $(95 \%$ Cl) \\
\hline Years since FCTC ratification & $1.23^{*}(1.02$ to 1.50$)$ \\
GDP per capita growth from 1999 to & $0.48 \dagger(0.28$ to 0.75$)$ \\
2014 & \\
State capacity & $0.90^{\star}(0.82$ to 0.99$)$ \\
Number of countries (observations) & 91 \\
\hline
\end{tabular}

${ }^{*} \mathrm{P} \leq 0.05 ; \dagger \mathrm{P} \leq 0.01$.

FCTC, Framework Convention on Tobacco Control; GDP, gross domestic product. 
tobacco taxes. Lack of success can be partly attributed to state fragility. More fragile countries in terms of security, political, economic and social development may not have administrative and technical capacity to implement high tobacco taxes. ${ }^{27-30}$ We did not detect an interaction between state capacity and time since FCTC ratification which indicates that weak state capacity as such may not prevent countries from ratifying FCTC. Promoting the FCTC should include strengthening of the basic functions of government. ${ }^{31} 32$

Countries with higher tax rates in 1998/1999 were more likely to have at least a $75 \%$ tax rate in 2014 . Increasing tobacco taxes requires determined action from governments. Countries that had higher tobacco taxes before the FCTC continued to do so also after ratifying it. The results indicate a path-dependency in tobacco taxation policies. ${ }^{33-35}$ The passing of tobacco tax policies is a contingent event that sets into motion institutional patterns that have deterministic properties. ${ }^{36}$ The result emphasises the importance of intensifying efforts to implement high tobacco taxes, especially in countries with originally low tax rates.

Surprisingly, lower, not higher, cigarette prices in $1998 / 1999$ were associated with $75 \%$ tobacco tax rates in 2014 (table 2). Countries with low cigarette prices in 1998/1999 may have reached the target with regular inflationary adjustments. This association may also reflect a possible ceiling effect where governments are reluctant to increase tobacco taxes if the cigarettes are already relatively expensive. This could also result from tobacco industry lobbying. ${ }^{2-9}$ FCTC Article 6 and its implementation guidelines expressly emphasise health goals in determining tobacco taxation. The health groups play an important role in creating awareness and building capacity for FCTC implementation. ${ }^{3037} 38$ It is also possible that it is easier for a country to reach the $75 \%$ tax rate if the price was low before the tax increase.

Consistent with earlier studies on cigarette affordability, cigarettes were more affordable in 2014 than in 1999 despite tax increases. ${ }^{2} 243940$ Our paper includes data collected well after 2010, so we have been able to base our analysis on a longer time horizon than earlier analyses and thereby confirm well-established trend in cigarette affordability. Countries that ratified FCTC earlier on average had less affordable cigarettes in 2014. The results seem to contradict the earlier finding of the non-significant association of FCTC ratification with having high cigarette taxes. It may well be that the FCTC prompted countries to increase tobacco taxes but not enough to obtain $50 \%$ or $75 \%$ tax rates. It is also possible that countries with already high tax rates were more likely to ratify FCTC earlier. If we include 199 tobacco tax rates in the model, FCTC ratification remains statistically significant.

There are many different ways that one could define an 'effective' tax rate, including $70 \%$ tax rate as specified in the WHO Technical Manual on Tobacco Tax Administration. ${ }^{1}$ The MPOWER set a target of $75 \%$ of price. Because this is a paper on the effect that the FCTC had on tax policy, we used the WHO's own standard of success as defined in MPOWER. The MPOWER measures for effective tax rates are arbitrary and different measures could also be used.

Our results emphasise the role of economic development in preventing cigarettes from becoming less affordable. If incomes rise quickly, cigarettes become more affordable even if taxes are kept constant. ${ }^{24}$ This development is reflected in our result where rapid per capita GDP growth between 1999 and 2014 has been associated with more affordable cigarettes in 2014. Among those 14 countries where the per capita GDP increased more than $300 \%$ in 15 years, cigarettes were less affordable in just three countries. In fact, the weakness of set tobacco tax rate targets, for example, $50 \%$ of retail price, is that they do not take into account the effect of rising incomes or industry pricing behaviour. Keeping other factors constant, the demand for cigarettes generally increases with the average level of income, especially in low-income and middle-income countries. ${ }^{24}$

Lack of state capacity was associated with both lower odds for having high tobacco taxes and less affordable cigarettes. Tobacco taxes are low and cigarettes are affordable in more fragile countries, while taxes are high and cigarettes less affordable in more stable countries. As of 2018, the multinational tobacco companies were targeting countries in Asia and Africa with young populations and relatively low smoking prevalence, especially among women. ${ }^{41}$

The tax provisions in the FCTC do not include specific tax targets. ${ }^{5}$ The unwillingness of FCTC parties to commit to minimum tax levels during FCTC negotiations is reflected in the lack of subsequent action. ${ }^{42}$ FCTC guidelines for Article 6 implementation recommend that parties should take into account 'both price elasticity and income elasticity of demand, as well as inflation and changes in household income, to make tobacco products less affordable over time in order to reduce consumption and prevalence'. ${ }^{5}$ Our results demonstrate that current policies for implementing tobacco taxes fail to meet this recommendation.

In our sample, cigarettes became more affordable from 1999 to 2014. Taking the FCTC guideline recommendation seriously would entail the conference of the FCTC parties assigning definite targets not only for tobacco tax rates but also for measures that prevent tobacco products from becoming more affordable.

The effect of cigarettes becoming more affordable with rapid income rises can be prevented by adopting adequate policies. ${ }^{39} 4043$ One example is a tax escalator which is adjusted to income growth or an equivalent variable that accounts for increases in consumer purchasing power. ${ }^{2}$ Such a tax escalator is already in place in the UK. ${ }^{44}$ With automatically increasing tobacco taxes by the increase in purchasing power the tobacco companies would increase prices which would prevent tobacco products not becoming more affordable. To allow this process to take place, tobacco tax 
rates could, at least temporarily, rise even above the $75 \%$ standard. Another option is to set a tax for each brand guaranteeing a $75 \%$ tax for every product. Doing so would make it more difficult for tobacco companies to downshift tax increases.

\section{Limitations}

Assessing the change in tax as a share of price over time can be complicated. ${ }^{19}$ Determination of tax rates as a proportion of total cigarette retail price is dependent on changes in tax rates but also on changes in wholesale prices. Consequently, despite an increase in the tax on cigarettes, the share of excise and total taxes in the retail price could remain the same or shrink depending on how the tobacco companies respond to the tax increase. Similarly, the share of taxes in the final retail price might increase, even if there is no change in the tax levied on a pack of cigarettes. The FCTC might have prompted countries to increase tobacco taxes but not enough, given that the FCTC did not specify $50 \% / 75 \%$ tax rates as a requirement.

The Article 6 guidelines were adopted in 2014, 9years after the FCTC entered force and may have delayed parties' attention to implementing tax increases. Other analyses of health warning labels ${ }^{183}$ (Article 11), smokefree policies ${ }^{34}$ (Article 8) and advertising bans ${ }^{35}$ (Article 13), however, demonstrated an effect of FCTC ratification without considering the delay in adoption of the implementing guidelines for these articles.

To establish a baseline before FCTC, we used tobacco tax and price data from two different sources, WB survey from $1999^{20}$ and the International Tobacco Documentation Centre's 1998 International Fiscal Guide to Tobacco. Both data sources include information on retail price of the most-sold cigarette brand. The high correlation (0.947) for overlapping price information indicates the data have been collected in a substantially uniform manner. The correlation for tax data was lower (0.676). This lower correlation could indicate a measurement error in the datasets or it could indicate that tobacco taxes increased from 1998 to 1999 more dramatically than cigarette prices. Given the more reliable international standing, we deemed the WB survey more reliable than the International Fiscal Guide to Tobacco produced by the tobacco industry. We focused on the price and tax for the most-sold cigarette brand on all data sources including WHO data for $2014,{ }^{19}$ but were unable to confirm that definitions remained stable over time. The most-sold cigarette may not fully describe the effect of tobacco taxation to tobacco consumption. We did not analyse the tax structure. Our outcome variable, the share of all tobacco taxes of the most sold brand, does not fully capture the role of taxes in reducing demand for tobacco. Earlier research has shown the tobacco industry may simultaneously absorb the tax increases on its cheapest brands while overshifting taxes on premium brands. ${ }^{12}$ The higher the level of the excise and other taxes the less room for tobacco industry price differentiation strategies. We were not able to analyse how countries' tax policies have accounted for country-specific price and income elasticities.

In this study, we were not able to assess the causal effects. Besides the variables used in this study, other factors such as economic cycles, political leadership and tobacco control activity outside of FCTC may have affected the outcome variables.

Our analysis focused only on cigarettes, ignoring other categories of tobacco products, some of which (eg, bidi) were more prevalent in more fragile countries such as Bangladesh and India. ${ }^{45}$ Since we had data only from two time points, we were not able to assess trends in tax, price and affordability in prior periods.

\section{CONCLUSIONS}

In contrast to advertising restrictions, ${ }^{39}{ }^{35}$ health warning labels $^{33}$ and smoke-free environments, ${ }^{34}$ FCTC ratification has not been systematically followed regarding higher tobacco taxation. FCTC Article 6 does not stipulate specific tax rates. MPOWER tax rate targets were not introduced before 2008. The more specific FCTC Articles 8, 11 and 13 discuss smoke-free environments, health warnings and advertising bans that fall into domain of health government, while Article 6 concerns financial policy which falls under finance ministries. There need to be further efforts to increase finance ministries' knowledge of and responsibility to implement Article 6 . Fragile countries are less likely to have high tobacco taxes. Rapid rise in incomes undermines the effectiveness of tobacco taxes. Guidelines for FCTC Article 6 implementation should assign definite targets for tobacco taxes and for the implementation of a tax escalator that gradually increases taxes to match the rising income levels. The tobacco control community should collaborate with other parts of civil society to intensify efforts to help more fragile countries to improve performance in FCTC implementation both through strengthening their administrative and technical capacity and through supporting the basic functions of government. The FCTC conference of the parties should assign definite targets not only for tobacco tax rates but also for measures to prevent tobacco products from becoming more affordable.

Contributors HH developed the idea for this study and carried out the data collection. HH and SG carried out the data analysis and wrote and revised the manuscript.

Funding This work was supported by National Cancer Institute grant CA-087472. Competing interests None declared.

Patient consent Not required.

Provenance and peer review Not commissioned; externally peer reviewed.

Data sharing statement № data are shared since we are using data which are already made public.

Open access This is an open access article distributed in accordance with the Creative Commons Attribution Non Commercial (CC BY-NC 4.0) license, which permits others to distribute, remix, adapt, build upon this work non-commercially, and license their derivative works on different terms, provided the original work is properly cited, appropriate credit is given, any changes made indicated, and the use is non-commercial. See: http://creativecommons.org/licenses/by-nc/4.0/. 


\section{REFERENCES}

1. World Health Organization. WHO technical manual on tobacco tax administration. Geneva, 2010.

2. World Health Organization. WHO report on the global tobacco epidemic 2015: raising taxes on tobacco. Geneva: World Health Organization, 2015.

3. Jha P, Chaloupka FJ. The economics of global tobacco control. BMJ 2000;321:358-61.

4. International Agency for Research on Cancer. IARC handbooks of cancer prevention: tobacco control. Volume 14: effectiveness of tax and price policies for tobacco control. Lyon, France: IARC, 2011.

5. World Health Organization. Framework convention on tobacco control. Geneva, 2003.

6. FCTC/COP/6/7. Guidelines for implementation of Article 6 of the WHO FCTC, 2014

7. Campbell RB, Balbach ED. Cigarette excise taxes in context: cautionary lessons from the U.S. experience. Int J Health Serv 2015;45:564-77.

8. Campbell RB, Balbach ED. Building alliances in unlikely places: progressive allies and the Tobacco Institute's coalition strategy on cigarette excise taxes. Am J Public Health 2009;99:1188-96.

9. Smith KE, Savell E, Gilmore AB. What is known about tobacco industry efforts to influence tobacco tax? A systematic review of empirical studies. Tob Control 2013;22:e1-53.

10. Campbell R, Balbach ED. Mobilising public opinion for the tobacco industry: the consumer tax alliance and excise taxes. Tob Control 2008;17:351-6.

11. Koch SF. Quasi-experimental evidence on tobacco tax regressivity. Soc Sci Med 2018;196:19-28.

12. Gilmore AB, Tavakoly B, Taylor G, et al. Understanding tobacco industry pricing strategy and whether it undermines tobacco tax policy: the example of the UK cigarette market. Addiction 2013;108:1317-26.

13. Chaloupka FJ, Cummings KM, Morley CP, et al. Tax, price and cigarette smoking: evidence from the tobacco documents and implications for tobacco company marketing strategies. Tob Control 2002;11(Suppl 1):i62-i72.

14. Brock B, Choi K, Boyle RG, et al. Tobacco product prices before and after a statewide tobacco tax increase. Tob Control 2016;25:166-73.

15. Alamar B, Mahmoud L, Glantz SA. Cigarette smuggling in California: fact and fiction. Tobacco control policy making: United States. San Francisco: Center for Tobacco Control Research and Education, UC San Francisco, 2003.

16. Hirono KT, Smith KE. Australia's $\$ 40$ per pack cigarette tax plans: the need to consider equity. Tob Control 2018;27.

17. David PA. Clio and the economics of QWERTY. The American Economic Review 1985;75:332-7.

18. Hiilamo H, Glantz SA. Implementation of effective cigarette health warning labels among low and middle income countries: state capacity, path-dependency and tobacco industry activity. Soc Sci Med 2015;124:241-5.

19. World Health Organization. WHO report on the global tobacco epidemic 2015, dataset. Geneva: World Health Organization, 2015.

20. Yurekli A, de Beye J. Design and administer tobacco taxes. World Bank economics of tobacco toolkit; no. 4. design and administration. Washington D.C.: World Bank, 1999.

21. McDaniel PA, Intinarelli G, Malone RE. Tobacco industry issues management organizations: creating a global corporate network to undermine public health. Global Health 2008;4:2.

22. International Tobacco Documentation Centre. International fiscal quide to tobacco. World taxation, price, tariff and regulatory information. Philip Morris, 1998.

23. World Bank. Country and lending groups, 2016.

24. Blecher E, van Walbeek C. An analysis of cigarette affordability. Paris: International Union Against Tuberculosis and Lung Disease, 2008.
25. Marshall MG, Cole BR, Report G, 2014. Global Report 2014. Conflict Governance and State Fragility: Center for Systemic Peace. http:// www.systemicpeace.org/SFImatrix2010c.pdf (accessed 31 Jan 2014).

26. World Health Organization. 2014 global progress report on implementation of the WHO Framework Convention on Tobacco Control, 2014.

27. Crosbie E, Sebrié EM, Glantz SA. Tobacco industry success in Costa Rica: the importance of FCTC article 5.3. Salud Publica Mex 2012;54:28-38.

28. Crosbie E, Sosa P, Glantz SA. Costa Rica's implementation of the framework convention on tobacco control: overcoming decades of industry dominance. Salud Publica Mex 2016;58:62-70.

29. Crosbie E, Sosa P, Glantz SA. Defending strong tobacco packaging and labelling regulations in Uruguay: transnational tobacco control network versus Philip Morris International. Tob Control 2018;27.

30. Crosbie E, Sosa P, Glantz SA. The importance of continued engagement during the implementation phase of tobacco contro policies in a middle-income country: the case of Costa Rica. Tob Control 2017;26:60-8.

31. Bump JB, Reich MR. Political economy analysis for tobacco control in low- and middle-income countries. Health Policy Plan 2013;28:123-33.

32. Leischow SJ, Ayo-Yusuf O, Backinger CL. Converging research needs across framework convention on tobacco control articles: making research relevant to global tobacco control practice and policy. Nicotine Tob Res 2013;15:761-6.

33. Sanders-Jackson AN, Song AV, Hiilamo H, et al. Effect of the framework convention on tobacco control and voluntary industry health warning labels on passage of mandated cigarette warning labels from 1965 to 2012: transition probability and event history analyses. Am J Public Health 2013;103:2041-7.

34. Uang R, Hiilamo H, Glantz SA. Accelerated adoption of smokefree laws after ratification of the world health organization framework convention on tobacco control. Am J Public Health 2016;106:166-71.

35. Hiilamo H, Glantz S. FCTC followed by accelerated implementation of tobacco advertising bans. Tob Control 2017;26.

36. Mahoney J. Path dependence in historical sociology. Theory Soc 2000;29:507-48.

37. Crosbie E, Sosa P, Glantz SA. Defending strong tobacco packaging and labelling regulations in Uruguay: transnational tobacco control network versus Philip Morris International. Tob Control 2018;27:185-94

38. Uang R, Crosbie E, Glantz SA. Tobacco control law implementation in a middle-income country: Transnational tobacco control network overcoming tobacco industry opposition in Colombia. Glob Public Health 2018;13:1050-64.

39. Blecher E. Targeting the affordability of cigarettes: a new benchmark for taxation policy in low-income and-middle-income countries. Tob Control 2010;19:325-30

40. Blecher E, Ross H, Leon ME. Cigarette affordability in Europe. Tob Control 2013;22:e6.

41. Gilmore AB, Fooks G, Drope J, et al. Exposing and addressing tobacco industry conduct in low-income and middle-income countries. Lancet 2015;385:1029-43.

42. Wipfli H. The global war on tobacco. Mapping the world's first public health treaty. Baltimore: Johns Hopkins University Press, 2016.

43. Blecher E, Ross H, Stoklosa M. Lessons learned from cigarette tax harmonisation in the European Union. Tob Control 2014;23:e12-e14.

44. Campaign for Tobacco-Free Kids. Tobacco tax success story. United Kingdom, Washingon, 2012.

45. Sinha DN, Gupta PC, Kumar A, et al. The poorest of poor suffer the greatest burden from smokeless tobacco use: A study from 140 countries. Nicotine Tob Res 2017. doi: 10.1093/ntr/ntx276. [Epub ahead of print 22 Dec 2017]. 